\title{
NOTES ON THE BATS OF THE GENUS MOLOSSUS.
}

\author{
By Gerrit S. Miller, JR., \\ Curator, Division of Mammals, United States National Museum.
}

Having recently examined the entire series of bats of the genus Molossus in the United States National Museum, ${ }^{1}$ I find that the number of recognized forms must be increased from 13 to at least 18. Such large areas of South America are still unrepresented, however, that no definitely monographic treatment of the genus is now possible. The following key and brief diagnoses are intended merely to place on record such results as have been reached.

The systematic history of the genus Molossus begins with a specimen from Martinique described by Daubenton under the name "mulot-volant" in the Memoires of the Royal Academy of Sciences, Paris, for the year 1759." The same animal appears as an "autre chauve-souris" in Buffon's Natural History, volume 10, pages 84-87, plate 19, figure 1. Here it is accompanied by a smaller individual also called an "autre chauve-souris," nothing is said. The length of forearm of the larger specimen as represented on the plate exactly agrees with that recorded in the text (p. 86). Assuming that the smaller animal, the dimensions of which were not published, was as carefully treated by the artist De Seve, there is no reason to suppose that it belonged to another species or that it originated elsewhere than in Martinique, since the lengths of the two forearms, $38 \mathrm{~mm}$. and $36 \mathrm{~mm}$., respectively, are within the known extremes of individual variation in the local race occurring on the islands of Dominica and Trinidad, and at Macuto, Venezuela. Therefore until the Martinican animal can be shown to differ from this race such technical names as were based on the two

\footnotetext{
1 Dr. J. A. Allen has kindly lent me some important material from the American Museum of Natural History, including the types of Molossus verrilli and M. sinaloæ. I have also had the opportunity to study, through the courtesy of Mr. Samuel Henshaw, the specimens in the Museum of Comparative Zoology, whose measurements have been recorded by Dr. Glover M. Allen (Notes on Chiroptera: Bull. Mus. Comp. Zool., vol. 52, pp. 59 and 60, July, 1908).

2 Page 387. Volume published in 1765.

8 Pages 87-88, pl. 10, fig. 2.
} 
"autre chauve-souris" of plate 19 should be regarded as applying to the somewhat wide ranging form in question. ${ }^{1}$ These names are four: On the larger specimen, Vespertitio molossus major Kerr, 1792, and Molossus fusciventer Geoffroy, 1805; on the smaller specimen, V. molossus minor Kerr, 1792, and Molossus longicaudatus Geoffroy, 1805.

Buffon's plate 19 is an important element in the history of another name, the Vespertilio molossus of Pallas. This was first published in $1766,{ }^{2}$ while additional data, including a figure of the skull, appeared during the subsequent year. ${ }^{3}$ The name was based on a specimen in the possession of Pallas, not improbably from Surinam, though no direct information is given concerning its origin. The figure shows conclusively that the animal was a Nyctinomus of the "macrotis" group. Pallas, however, supposed that his bat was the same as the one figured by Buffon, to whose plate he refers as a good representation of those characters of head and lips that suggested to him the specific name molossus. ${ }^{4}$

This confusion of two distinct animals under the specific name molossus continued through the rest of the eighteenth century. In 1805 Geoffroy increased it by proposing a generic name Molossus for the bats to which the specific name had previously been applied, ${ }^{5}$ and then basing his account of the technical characters of the group on one of the specimens (the smaller) figured by Buffon. Although Geoffroy evidently regarded the Vespertitio molossus of Pallas as identical with one or the other of Buffon's specimens, he applied a new name to each: fusciventer to the larger and longicaudatus to the smaller, probably because he believed that this was made necessary by the transfer of the old specific name from a species to a genus. In the same paper Geoffroy described seven other members of the genus, all technically named for the first time. The group therefore contained nine supposedly distinct forms. By tautonymy its type must be Vespertitio molossus. Since Geoffroy makes no direct reference to Pallas in connection with this name, the type-species should be construed in the wider sense of "molossus Auct." As first reviser I now restrict the name, under the provisions of the International Code, art. $30 \mathrm{~g}$, to that portion of the composite species

1 On St. Lucia and Barbados a slightly larger form oceurs. This appears to be identical with Molossus sobcurus of British Guiana. It is not impossible that true major may prove to be this larger animal, in which event a readjustment of names will be required.

2 Miscellanea Zoologica, p. 49.

3 Spicilegia Zoologica, fasc. 3, p. 8, pl. 4, fig. 11.

4 The name $N$ yctinomus molossus (Pallas) should be applied to the "macrotis" of northern South America, reserving Gray's name for the local Jamaican form.

5 Ann. Mus. Hist. Nat. Paris, vol. 6, pp. 151-154. " "Reservant au vesp. leporinus le nom de Noctilio. . . . j'ai érigé en nom générique celui de molossus qui n’a désigné jusqu'ici qu’une espèce, et qui m’a paru propre a faire connoître toutes celles qu'on a souvent été dans le cas de coniondre sous la même dénomination." 
which Geoffroy knew at first hand and from which he derived his technical characters. The generic name Molossus therefore continues to be applied to the group for which it is in current use, though with M. major (Kerr) $=$ Vespertilio molossus of authors (part) form Martinique as the type.

\section{KEY TO THE BATS OF THE GENUS MOLOSSUS.}

Greatest breadth across upper canines $5 \mathrm{~mm}$. or more (rufus-group).

Forearm 47-51 mm.; greatest length of skull 21-23 mm.

Color brownish (French Guiana to Peru and Paraguay)........ rufus (p. 88).

Color blackish (Mexico)............................. nigricans (p. 88).

Forearm 43-47.5; greatest length of skull 19-21.3 mm.

Color light and dull (Mexico to Panama)................ sinaloæ (p. 89).

Color dark and rich (Venezuela).................... pretiosus (p. 88).

Greatest breadth across upper canines less than $5 \mathrm{~mm}$.

Greatest length of skull 18-18.6 mm. (currentium-group).

Color with a decided tendency toward broccoli-brown and drab (Argentina). currentium (p.89).

Color a rich dark brown (Central America and northern South America)

Greatest length of skull $14.8-17.4 \mathrm{~mm}$.

bondæ (p. 89).

Forearm 33-37 mm. (pygmæus-group).

Braincase unusually inflated, its greatest width about $9 \mathrm{~mm}$. (British Guiana)................................... burnesi (p. 91).

Braincase normal, its greatest width about $8 \mathrm{~mm}$.

General color a light brown usually much tinged with drab, especially on underparts (Curaçao, Peru, and Ecuador) ...........

pygmæus (p. 92).

General color a clear brown rarely if ever distinctly tinged with drab.

Upper parts very dark, usually something between burnt-umber and seal-brown (Panama)...................... coibensis (p. 92.)

Upper parts not very dark, usually something between rawumber and wood-brown (Cuba).......tropidorhynchus (p. 92).

Forearm 36-41 mm. (obscurus-group).

Lower leg 19-21.6 mm.; greatest length of skull 15-16.4 mm.

Molars averaging larger (Dominica, [Martinique], Trinidad, Venezuela) .......................................

Molars averaging smaller (St. Kitts, Nevis, Antigua, Montserrat).

debilis (p. 90).

Lower leg 20-23.8 mm.; greatest length of skull 16-17.4 mm.

Lower leg usually more than $22.6 \mathrm{~mm}$. (22-23.8 mm.)

Rostrum normal (Porto Rico)................ fortis (p. 89).

Rostrum short and heavy.

Molars large (Jamaica)............... fuliginosus (p. 90).

Molars small (Santo Domingo).............. verrilli (p. 90).

Lower leg usually less than $22.6 \mathrm{~mm}$. (21-22.6 mm.)

Underparts with a decided tinge of drab (Mexico). aztecus (p. 91).

Underparts without decided tinge of drab.

General color moderately dark, approaching raw-umber (Paraguay)...................... crassicaudatus (p. 91).

General color very dark, burnt-umber or darker (Brazil, British Guiana, Barbados, St. Lucia)...obscurus (p. 91). 
First or rufus-group.-Largest members of the genus, with length of forearm ranging from 43 to $51 \mathrm{~mm}$, greatest length of skull from 19 to 23 $\mathrm{mm}$; skull with highly developed sagittal crest, and with rostral breadth across canines $5 \mathrm{~mm}$ or more.

\section{MOLOSSUS RUFUS Geoffroy.}

1805. Molossus rufus Geoprroy, Ann. Mus. Hist. Nat., Paris, vol. 6, p. 155. (Cayenne.) $^{1}$

1805. Molossus castaneus Geoffroy, Ann. Mus. Hist. Nat., Paris, vol. 6, p. 155. (Paraguay.)

1823. Molossus ursinus Spix, Sim. et Verpert. Brasil Sp. Nov., p. 59. (Vicinity of Para, Brazil.)

1827. Dysopes alecto Temminck, Monogr. de Mamm., vol. 1, p. 231. (Interior of Brazil.)

1844-46. Molossus myosuros Tschudi, Fauna Peruana, Mamm, p. 83. (Peru.) 1891. Molossus fuminensis Lataste, Ann. Mus. Civ. Stor. Nat., Genova, ser. 2, vol. 10, p. 658 . (Rio Janeiro, Brazil.) Name based on a normal specimen of Molossus rufus whose characters differ in important details from those in Dobson's faulty description.

Size maximum for the genus; forearm in males 48.5-51 $\mathrm{mm}$, in females 47-51; greatest length of skull in males 21.4-23, in females 20.4-22; general color a reddish brown varying in different individuals from russet to mummy-brown, the blackish phase apparently unusual. Specimens examined from Cayenne, Peru (type of $M$. myosuros; forearm $48 \mathrm{~mm}$ ), southern Brazil (São Paulo), and Paraguay (Sapucay and Villa Rica).

\section{MOLOSSUS NIGRICANS Miller.}

1902. Molossus nigricans Mrluer, Proc. Acad. Nat. Sci. Philadelphia, p. 395. September 12, 1902. (Acaponeta, Tepic, Mexico.)

Like Molossus rufus but color usually a deep, blackish brown. Specimens examined from Tepic (Acaponeta), Vera Cruz (Catemaco and San Andres Tuxtla), and Yucatan (Chichen Itza and Yaxcash).

\section{MOLOSSUS PRETIOSUS Miller.}

1902. Molossus pretiosus Miller, Proc. Acad. Nat. Sci. Philadelphia, p. 396. September 12, 1902. (La Guaira, Venezuela.)

Size not so great as in Molossus rufus; forearm in males 44.5-47.5 $\mathrm{mm}$, in females 43.5-46; greatest length of skull in males 20.5-21.5, in females 19-20.7; general color a rich dark brown varying from a reddish seal-brown almost to chestnut, the blackish phase not unusual. Specimens examined from La Guaira, Venezuela, and vicinity.

\footnotetext{
1 Thomas (Ann. and Mag. Nat. Hist., ser. 7, vol. 8, p. 437, November, 1901) assumes that the animal originally came from Brazil, but Geoffroy expressly states (p. 154) that his species of Molossus, other than those known to Azara, were sent from "North America, Surinam, and chiefly from Cayenne." A male from Cayenne and two males from "America," which I examined in the Paris Museum in 1904 (the two without exact locality marked "type," but the authenticity of this indication open to question) represent a large form like rufus (forearm in the two "types" 49 and $50 \mathrm{~mm}$ ). Further material from French Guiana is needed to show whether Molossus rufus and the Paraguayan M. castaneus are distinct.
} 


\section{MOLOSSUS SINALOE Allen.}

1906. Molossus sinaloæ Allen, Bull. Amer. Mus. Nat. Hist., vol. 22, p. 236. July 25, 1906. (Escuinapa, Sinaloa, Mexico.)

Like Molossus pretiosus but color a dark brownish drab. Specimens examined from Sinaloa (Escuinapa), Yucatan (Yaxcash), Honduras (Chamalicon), Nicaragua (Graytown), and Panama (Punta de Peña).

Second or currentium-group. - Size less than in the rufus-group; forearm ranging from 39 to $42 \mathrm{~mm}$, greatest length of skull from 18 to 18.6 $\mathrm{mm}$; rostral breadth across canines slightly less than $5 \mathrm{~mm}$.

\section{MOLOSSUS CURRENTIUM (Thomas).}

1901. Molossus obscurus currentium Thомаs, Ann. and Mag. Nat. Hist., ser. 7, vol. 8, p. 438. November, 1901. (Goya, Corrientes, Argentina.)

Size less than in the members of the rufus-group; greatest length of skull, 18-18.6 mm.; greatest breadth across upper canines less than $5 \mathrm{~mm}$; general color a dark brownish drab. Specimens examined from Argentina (Goya) and Brazil (Manaos and Obydos).

\section{MOLOSSUS BONDE Allen.}

1904. Molossus bondæ Allen, Bull. Amer. Mus. Nàt. Hist., vol. 20, p. 228. June 29, 1904. (Bonda, Santa Marta, Colombia.)

Like Molossus currentium but color very dark, approaching the seal-brown of Ridgway. Specimens examined from Nicaragua (Greytown) and Panama (Chorrera, Am. Mus. Nat. Hist.).

Third or obscurus-group.--Length of forearm usually less than in the members of the currentium-group but seldom falling below $37 \mathrm{~mm}$. (36-41 mm.) ; skull constantly smaller (greatest length, 15-17.4 mm.).

\section{MOLOSSUS FORTIS, new species.}

Type.-Adult male (in alcohol). Cat. No. 102319, U. S. National Museum. Collected at Luquillo, Porto Rico, March 5, 1900, by L. Stejneger and C. W. Richmond.

Size maximum for members of the obscurus-group; lower leg and foot usually more than $22.6 \mathrm{~mm}$. (22-23.8 mm.); skull and teeth normal. Measurements of type: head and body, $66 \mathrm{~mm}$; tail, 37.5; tibia and foot, 23 ; forearm, 40 ; third digit, 81 ; fifth digit, 43 ; greatest length of skull, 17.5; condylobasal length, 16.0; breadth of braincase, 8.9 ; mandible, 12.2 ; maxillary toothrow exclusive of incisors, 6.6 ; mandibular toothrow exclusive of incisors, 7.2. Confined to Porto Rico. 


\section{MOLOSSUS PULIGINOSUS Gray.}

1838. Molossus fuliginosus Grax, Mag. Zool. and Bot., vol.2, p. 501. February, 1838. (Jamaica. See Dobson, Catal. Chiropt. Brit. Mus., p. 413, 1878.)

Like Molossus fortis from Porto Rico, but rostral portion of skull obviously shortened; teeth normal. Confined to Jamaica.

\section{MOLOSSUS VERRILLI Allen.}

1908. Molossus verrilli Allen, Bull. Amer. Mus. Nat. Hist., vol. 24, p. 581. September 11, 1908. (Samana, Santo Domingo.)

Agreeing with Molossus fuliginosus in general characters and in form of rostrum, but molars decidedly reduced in size. Confined to Santo Domingo; type specimen examined.

\section{MOLOSSUS MAJOR (Kerr).}

1792. V[espertilio] mol[ossus] major KerR, Anim. Kingd., p. 97. Based on Schreber's plate 59, lower figure (=Buffon, vol. 10, pl. 19, fig. 2). Martinique.

1792. V[espertilio] mol[ossus] minor KerR, Anim. Kingd., p. 97. Based on Schreber's plate 59, upper figure (=Buffon, vol. 10, pl. 19, fig. 1). Probably from Martinique.

1805. Molossus longicaudatus Geoffroy, Ann. Mus. Hist. Nat., Paris, vol. 6, p. 155. Based on the specimen represented by Buffon, vol. 10, pl. 19, fig. 2 . (Martinique.)

1805. Molossus fusciventer Geoffroy, Ann. Mus. Hist. Nat., Paris, vol. 6, p. 155. Based on Buffon, vol. 10, pl. 19, fig. 1. (Probably from Martinique).

Smaller than Molossus obscurus and its immediate allies crassicaudatus and aztecus, lower leg and foot usually less than $21 \mathrm{~mm}$. (19-21.6 mm.); teeth normal. Specimens examined from Dominica, Trinidad, and Venezuela (Macuto).

\section{MOLOSSUS DEBILIS, new species.}

Type--Adult female (in alcohol) Cat. No. 110935, U. S. National Museum. Collected on St. Kitts, Lesser Antilles, in 1901, by W. H. Alexander.

Like Molossus major but crown area of molars decidedly reduced. Measurements of type: head and body, $56.6 \mathrm{~mm}$.; tail, 36; tibia and foot, 20.4; forearm, 38; third digit, 74; fifth digit, 42 ; greatest length of skull, 15.4; condylobasal length, 14.0; breadth of braincase, 8.2; mandible, 10.6; maxillary toothrow exclusive of incisors, 5.4 ; mandibular toothrow exclusive of incisors, 5.0. Specimens examined from St. Kitts, Nevis, Antigua, and Montserrat. 


\section{MOLOSSUS OBSCURUS Geoffroy.}

1805. Molossus obscurus Geoffroy, Ann. Mus. Hist. Nat., Paris, vol. 6, p. 155. Surinam (name definitely applied to specimens from Surinam, one of the localities mentioned by Geoffroy, by Temminck, Monogr. de Mamm., vol. 1, 1826, p. 236-237).

1820. Molossus acuticaudatus Desmarest, Mammalogie, p.116. (Brazil.)

1826. Dysopes velox Temminck, Monogr. de Mamm., vol. 1, p. 234. (Brazil.) 1850. Dysopes olivaceofuscus WaGner, Abh. Math.-Phys. Classe, k. bayer. Akad.

Wissensch., München, vol. 5, p. 202. (Cuyaba, Matto Grosso, Brazil.)

1850. D[ysopes] amplexicaudus WAGner, Abh. Math.-Phys. Classe, k. bayer.

Akad. Wissensch., München, vol. 5, p. 202. (Caicara, Matto Grosso, Brazil.)

Size less than in the large Antillean species; lower leg and foot usually less than $22.6 \mathrm{~mm}$. (21-22.6 mm.; general color a rich brown at least as dark as the burnt-umber of Ridgway. Specimens examined from eastern Peru (Perené, Dept. of Junin), Brazil (Bahia, Marajo, Para?, San Paulo, Santarem), British Guiana (Berbice), and the islands of Barbados and St. Lucia.

\section{MOLOSSUS CRASSICAUDATUS Geuffro}

1805. Molossus crassicaudatus Geoffroy, Ann. Mus. Hist. Nat., Paris, vol. 6, p. 156. (Paraguay).

Like Molossus obscurus but color not so dark (usually approaching the raw-umber of Ridgway). Specimens examined from Paraguay (Tacuaral and Villa Rica).

MOLOSSUS AZTECUS Saussure.

1860. M[olossus] aztecus Saussure, Revue et magasin de zoologie, ser. 2, vol. 12, p. 283, July, 1860. (Amecameca, Mexico.)

Like Molossus crassicaudatus but underparts with a decided tinge of drab. Specimens examined from Chiapas (Huehuetan).

Fourth or pygmæus-group.-Smallest members of the genus, with length of forearm ranging from 33 to $37 \mathrm{~mm}$.

\section{MOLOSSUS BURNESI Thomas.}

1905. Molossus burnesi Tномаs, Ann. and Mag. Nat. Hist., ser. 7, vol. 15, p. 584. June, 1905. (Cayenne, French Guiana.)

According to the description this species differs from all other known members of the genus in the unusual inflation of the braincase; greatest length of skull $16.2 \mathrm{~mm}$., breadth of braincase 8.9. (In other forms with skull of same length the breadth of braincase is about $8 \mathrm{~mm}$.) Known from the type only; no specimens seen. 


\section{MOLOSSUS PYGMAUS Miller.}

1900. Molossus pygmæus Mrluer, Proc. Biol. Soc. Washington, vol. 13, p. 162.

October 31, 1900. (Willemstad, Curaçao.)

Color a light brown, the general effect usually ranging between the drab and hair-brown of Ridgway, some trace of drab always present, at least on underparts. Skull normal. Specimens examined from Curaçao, Equador (Guayaquil, Santa Rosa), and northwestern Peru (Piura).

\section{MOLOSSUS COIBENSIS Allen.}

1904. Molossus coibensis Allen, Bull. Amer. Mus. Nat. Hist., vol. 20, p. 227. June 29, 1904. (Coiba Island, Panama.)

Like Molossus pygmæus Miller, but color very dark, usually ranging between the burnt-umber and seal-brown of Ridgway. Specimens examined from the following localities in Panama: Ancon, Chorrera, Culebra, Paraiso, San Pablo, and Tabernilla.

\section{MOLOSSUS TROPIDORHYNCHUS Gray.}

1839. Molossus tropidorhynchus Gray, Ann. Nat. Hist., vol. 4, p. 6. September, 1839. (Cuba.)

Like Molossus pygmæus and M. coibensis, but color a light brown usually ranging between the raw-umber and wood-brown of Ridgway, and with no evident trace of drab. Confined to Cuba. 


\section{$2 \mathrm{BHL}$ Biodiversity Heritage Library}

Miller, Gerrit S. 1913. "Notes on bats of the genus Molossus." Proceedings of the United States National Museum 46, 85-92.

View This Item Online: https://www.biodiversitylibrary.org/item/32859

Permalink: https://www.biodiversitylibrary.org/partpdf/34076

\section{Holding Institution}

Smithsonian Libraries

\section{Sponsored by}

Smithsonian

\section{Copyright \& Reuse}

Copyright Status: NOT_IN_COPYRIGHT

This document was created from content at the Biodiversity Heritage Library, the world's largest open access digital library for biodiversity literature and archives. Visit BHL at https://www.biodiversitylibrary.org. 